\title{
Studies Review
}

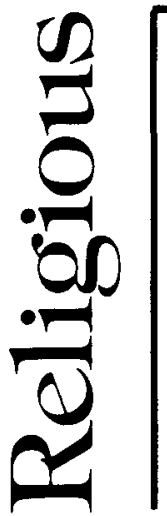

A publication like Religious Studies Review has been needed for a long time in our field. We now have in the Review a thoroughly responsible organ dedicated to reviewing the critical books in the field of religion and related disciplines-it is high time and many of us are very, very grateful for it.

Sally McFague, Dean, Vanderbilt Divinity School

Religious Studies Review is a sign of maturity in the discipline, and a guide to the wealth of resources now available. Its scholarly approach and critical stance provide perspective in an area tempted to live beyond its means.

Joseph C. McLelland, Dean, Faculty of Religious Studies

McGill University

Religious Studies Review dramatically documents the extent to which American scholarship in religion has come of age after having achieved corporate self-consciousness only so recently. In the Review Essays each issue of $R S R$ bristles with material relevant for anyone concerned with religious studies in its wider scope, while the Notes on Recent Publications, organized according to topic areas, provide prompt contact with the stream of books and monographs that continue to emerge from presses throughout the world. The listing of recently completed Dissertations in Religion is an added bonus.

Robert A. Kraft, Chairperson, Department of Religious Studies

University of Pennsylvania

I have become an enthusiastic, regular reader of Religious Studies Review. It keeps me abreast of scholarly developments and current literature in my own and in other fields in a helpful, readable way.

Robert T. Handy, Academic Dean and Professor of Church History

Union Seminary, New York, and Adjunct Professor of Religion

Columbia University

\section{Annual Subscription Rates}

Individuals belonging to member societies of the CSR: $\$ 10.00$ Others (including institutions): $\$ 15.00$

Make checks payable to Council on the Study of Religion, and mail to Council on the Study of Religion, Wilfrid Laurier University, Waterloo, Ontario N2L 3C5 


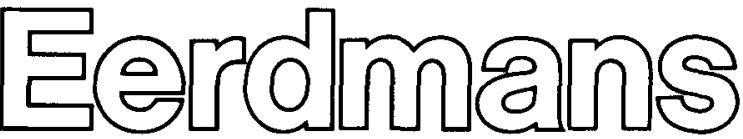 ...expanding the horizons of contemporary religious thought.}

\section{EVANGELICAL THEOLOGY: \\ An Introduction \\ Karl Barth \\ Based on lectures delivered during his visit to the U.S in 1962, here is what Barth described as "a short account of what, up to now. I have basically sought, learned, and represented from among all the paths and detours in the field of evangelical theology."}

Published

paper, $\$ 5.95$

\section{AN INTRODUCTION TO THE THEOLOGY OF KARL BARTH}

Geoffrey W. Bromiley

An informed and helpful summary.

structured in terms of the 12-volume

Church Dogmatics, "...remarkably balanced and judicious in its selection of emphases... Written with great clarity... There could hardly be offered a better or more trustworthy guide to students and to mature theologians in their study of Barth's Dogmatics.'

- Thomas F. Torrance

Published

paper, $\$ 7.95$

\section{CHRISTIAN FAITH: An Introduction}

\section{to the Study of the Faith}

Hendrikus Berkhof

In a major new examination of the basis and practice of Christian faith, a distinguished scholar provides original and stimulating responses to profoundly important questions about the nature of belief.

"A thought-provoking and often controversial analysis of some of the great themes of the Christian Faith."

- Donald $G$. Bloesch

February

\section{INCARNATION AND MYTH: The Debate Continued}

Michael Goulder, editor

Participants in this spirited colloquy on 1977's controversial The Myth of God Incarnate-including Maurice Wiles, Brian Hebblethwaite, Lesslie Newbigin. John Hick and Charles Moule-debate and expand upon the issues raised by the earlier volume.

Published

paper, $\$ 5.95$

JOHN R. MOTT, 1865-1955:

A Biography C. Howard Hopkins

Acknowledged as the leading ecumenical statesman of the Protestant world throughout the first half of the 20th century, Mott earned a Nobel Peace Prize in 1946 for his diplomatic and humanitarian achievements.

"Hopkins' very detailed, very personal biography will reintroduce this ecumenical and evangelical giant... to thousands who are indebted to him but know him not."-Creighton Lacy.

March

illustrated; cloth, $\$ 22.50$

\section{ISSUES OF THEOLOGICAL CONFLICT (Revised)}

Richard J. Coleman

"The determining issues of the immediate future"-biblical authority and cultural subversion - receive Coleman's special attention in this up. dated examination of the contemporary theological scene

April 
THE BOOK OF JEREMIAH (NICOT) John A. Thompson

The concept of covenant is central to this exposition, the fouth volume released in The New International Commentary on the Old Testament.

March

cloth, $\$ 15.95$

THE SPREADING FLAME F.F. Bruce The rise and progress of Christianity. from its first beginnings to the conversion of the English, is traced in this reprint edition of a classic reference volume Published paper, $\$ 7.95$

\section{THE MINISTRY OF THE WORD}

D.W. Cleverley Ford

Thirty-five years' experience in the parish ministry informs this lively and realistic discussion of the problems facing today's ministers.

Published

cloth, $\$ 13.95$

THE SAYINGS OF JESUS T.W. Manson This commentary on the recorded words of the Savior, notes The Times Literary Supplement, is "invaluable to everyone engaged in the study of the New Testament."

Published

paper, $\$ 7.95$

\section{GOSPEL/LAW: Contrast}

or Continuum? Daniel P. Fuller

After exploring the underlying

principles of dispensationalism and covenant theology, the author of this search ing new study suggests a resolution of the apparent tension between grace and law

Published

paper, $\$ 3.95$

MISSION TRENDS NO. 4:

Liberation Theologies

Gerald H. Anderson and Thomas F.

Stransky, editors

Focusing on North American and

European Liberation Theologies, the fourth volume in this popular series looks at Black, Feminist, Asian-Americanand Native-American experiences.

Published

paper, $\$ 3.45$
ART IN ACTION Nicholas Wolterstorff Viewing the arts as multifunctional, Wolterstorff develops a Christian aesthetic that integrates ant with daily life

February

paper, $\$ 6.95$

\section{THE TWO HORIZONS}

Anthony $\mathrm{C}$. Thiselton

Combining a survey of the field of hermeneutics with an assessment of its limits as a tool for biblical interpretation Thiselton provides both clear exposition and critical insight.

February

cloth, $\$ 20.95$

\section{THE BIBLE IN ITS LITERARY MILIEU}

John Maier and Vincent Tollers, editors

Twenty-five contributors address concerns of literary as well as biblical scholarship, providing new understanding of the scriptures

Published

paper, $\$ 10.95$

\section{THE TEXT OF THE OLD TESTAMENT}

Ernst Würthwein

A brodd survey of the original texts, translations and versions of the Old Testament, designed to aid in understanding the central problems of textual criticism.

Published

illustrated; cloth, $\$ 8.95$

Previously Announced

\section{INTERNATIONAL STANDARD BIBLE ENCYCLOPEDIA (Revised) \\ Volume 1, A-D}

Geoffrey W. Bromiley, General Editor

The first volume in this completely revised and updated version of a classic among biblical reference works is now available

Published

cloth, $\$ 29.95$

For a listing of Eerdmans recent and forthcoming theological titles. write for vour free copy of the latest Theologist Catalog PUBLISHING CO. 255 JEFFERSON AVE $S E$. GRAND RAPIDS MICH 4950. IN CANADA: OXFORD UNIVERSITY PRESS 


\section{EERDMANS '79: THEOLOGICAL EXPRESSIONS}

\section{Geoffrey W. Bromiley, et al, Editors \\ INTERNATIONAL STANDARD \\ BIBLE ENCYCLOPEDIA, REVISED: Volume I}

Now thoroughly revised, this established standard among scriptural reference works provides information on all biblical persons and places and on every significant biblical term and concept, and includes many fresh illustrations. Its hundreds of contributors, all respected for expertise in their respective areas of bible study, represent the best in international evangelical scholarship. ISBN 0-8028-8161-0 Cloth. 1030 pages. \$29.95 Until December $31,1979, \$ 27.50$

\section{Ray S. Anderson}

\section{THEOLOGICAL FOUNDATIONS FOR MINISTRY}

Carefully chosen selections from the works of leading theologians (including Barth, Bonhoeffer, Küng, Thielicke) develop a consistent theology of Christian ministry.

ISBN 0-0828-1776-9 Paper. 792 pages. 58.95

\section{Karl Barth}

\section{COME, HOLY SPIRIT}

More than two dozen sermons exemplify Barth's view of the preacher as ambassador of divine authority, and express the heart of his theology: God's revelation in Christ and man's utter dependence on grace.

ISBN 0-8028-1782-3

Paper, 308 pages, $\$ 4.95$

\section{Geoffrey W. Bromiley}

CHILDREN OF PROMISE: The Case For Baptizing Infants

Succinct, persuasive and scripturally based, Bromiley's argument in favor of infant baptism includes guidelines for churches wishing to examine the subject in greater detail.

ISBN $01-8028-1797.1 \quad$ Paper. 96 piges. $\$ 2.95$

\section{John W. de Gruchy \\ THE CHURCH STRUGGLE \\ IN SOUTH AFRICA}

Alan Paton contributes the Foreword to an enlightening discussion of the history. development and current status of the South African church, exploring its role in this politically and socially troubled land.

ISBN 0-8028-17\%6-6 Paper. 281) pages, $\$ 7.95$

\section{Norman Kraus}

\section{THE AUTHENTIC WITNESS:}

Credibility and Authority

Contending that the essential mark of the true church is its commitment to witness, Kraus urges the body of Christ to concentrate on a mission of reconciliation to the world.

ISBN 0-8028-1785-8 Paper, 192 pages, \$5.95

\section{Ernst Lange \\ AND YET IT MOVES}

The subject of how-indeed, of whether - the goal of church unity can be achieved is brilliantly analysed in this discussion of the strengths and weaknesses of the ecumenical movement.

ISBN $0-8028-1790-4 \quad$ Paper, 192 pages. $\$ 9.95$

\section{William Sanford LaSor}

HANDBOOK OF BIBLICAL HEBREW

Designed as a complete tool for the student of Biblical Hebrew, this threevolume set combines reading lessons with grammar, paradigms and basic vocabulary.

ISBN 0-8028-2379-3 Paper. three volumes. \$10.45 
Richard Lovelace

\section{COTTON MATHER: A Theology of} Christian Experience

Cotton Mather's emphasis on personal and private piety is the central theme in this study, which sees the union of Puritanism and Pietism in Mather as a major contributing influence on the Great Awakening and later religious revivals. A Christian University Press Publication ISBN (0-8028-1750)-5

Paper. $3(0)$ pages. $\$ 8.95$

\section{C.F. D. Moule}

\section{THE HOLY SPIRIT}

Addressing a broad range of questions relating to the nature and role of the Holy Spirit as presented in the New Testament, Moule provides a deeper understanding of the Spirit's importance in Christian doctrine and experience.

ISBN (1) $8028-1796-3 \quad$ Paper. 136 pages. $\$ 3.95$

\section{Helmut Thielicke}

\section{THEOLOGICAL ETHICS}

A landmark study in Christian ethics is now available for the first time in English in a matched, paperbound set.

Volume I: Foundations

ISBN (1-8028-1791-2

Volume 2: Politic

ISBN $0.802 x-1792-0$

Volume 3: Sex

ISBN ()-80)28-1794-7

The Set. Three Volumes

ISBN 0-8028-1795-5

Paper, 7.34 pages, $\$ 10.95$

Paper, 712 pages, $\$ 10.95$

Paper, 352 pages, $\$ 6.95$

$\$ 27.50$

\section{Peter Toon}

\section{THE DEVELOPMENT OF DOCTRINE} IN THE CHURCH

Recognizing that Christian doctrine is based ultimately on scripture, this survey of doctrinal development through the centuries notes its creedal formulations and examines the individuals and influences that have contributed to an understanding of the faith.

ISBN (0-8)28-1787-4

Paper. 1.44 pages. $\$ 4.95$

\section{Gordon Wenham \\ THE BOOK OF LEVITICUS (NICOT)}

The third volume released in The

New International Commentary on the Old Testament elucidates the original meaning of the text and applies its message to today"s church.

ISBN (0-8028-2353-X

Cloth. 368 pages. $\$ 9.95$

\section{PREVIOUSLY PUBLISHED}

\section{Geoffrey W. Bromiley HISTORICAL THEOLOGY: An Introduction}

"An admirable introduction to historical theology ... appears to be a readymade textbook capable of enticing the student to read the theologians themselves."-Theological Studies

ISBN 0-8028-3509-0

Cloth, 500 pages, $\$ 14.95$

\section{F. F. Bruce}

PAUL: Apostle of the Heart Set Free

"Noteworthy.... a most helpful tool for the study of the life and thought of Paul." - Reformed Review"

ISBN 0-8028-3501-5

Cloth, 496 pages. $\$ 13.95$

\section{Stephen Evans}

\section{SUBJECTIVITY AND RELIGIOUS BELIEF}

"Brings us to the heart of longstanding issues of knowledge and belief." - Paul L. Holmer, Yale Divinity School

A Christian University Press Publication ISBN 0-8028-1712.2 Paper, 250 pages, $\$ 5.95$

\section{Gerhard F. Hasel}

NEW TESTAMENT THEOLOGY:

Basic Issues in the Current Debate

"With its clear analysis of authors and issues (this book) is all but indispensable as a guide to the various New Testament theologies."-The Clergy Journal ISBN 0-8028-1733.5 Paper. 180 pages. $\$ 5.95$

\section{Howard Marshall, Editor}

NEW TESTAMENT

INTERPRETATION: Essays on

Principles and Methods

"Provides a persuasive introduction to critical methods for precisely those students who are most afraid of them." Religious Sudies Review.

ISBN 0-8028-3.503-1 Cloth. 336 pages, 512.95

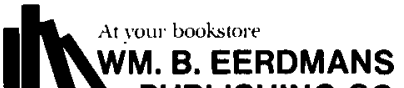
255 JEFFERSON AVE SE, GRAND RAPIOS. MICH 49503 In Canada: Oxford University Press.

70 Wynford Drive. Don Mills. Ontario M3C IJy 


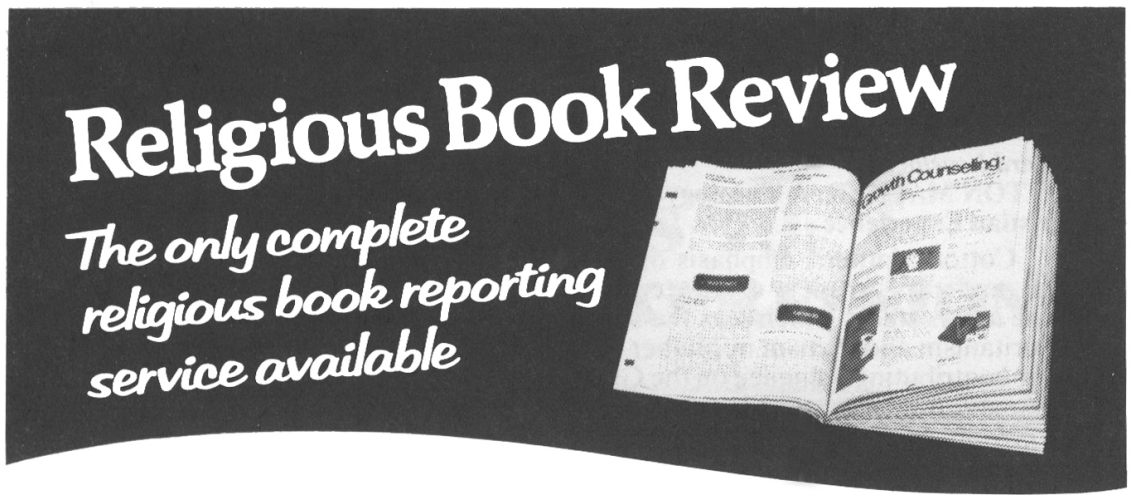

\section{NEW BOOK ANNOUNCEMENTS}

This section in each issue of Religious Book Review provides a complete descriptive listing of all announced religious interest titles alphabetically arranged by publisher.

\section{CURRENT INDEX TO RELIGIOUS BOOKS}

This section in each issue of Religious Book Review provides a completely annotated and descriptive listing according to subject classification of all religious interest titles published during each half year period.

\section{BOOK REVIEWS}

This section in each issue of Religious Book Review includes extended critical reviews of selected titles.

\section{AUDIO VISUAL REVIEW}

This section in each issue of Religious Book Review provides brief critical reviews of religious interest Cassettes, Films, Filmstrip Sets (Record or Cassette), and Records.

\section{SUBJECTS COVERED:}

Biblical Studies

Books for the Young

Ecumenical Works

Ethics

Family Life

Fine Arts

History and Biography

Literature and Language

Liturgy

Pastoral Theology

Philosophy and Psychology

Reference and Bibliography

Religion Today

Religions of the World

Religious Education

Science

Sermons and Homilies

Social Sciences

Spiritual Life

Theological Works

Miscellaneous

- For complete coverage on ALL new and recently published titles from scholarly theology to popular inspiration, subscribe to Religious Book Review - the only complete religious book reporting service available.

\section{RELIGIOUS BOOK REVIEW}

P.O. Box 1331

Roslyn Heights, N.Y. 11577

1 year $\$ 7$

Enter my subscription to RELIGIOUS BOOK REVIEW for

Name

Address

City State Zip

Payment enclosed. $\square$ Please bill. Your satisfaction is guaranteed or the unused portion of your subscription fee will be returned. 


\section{Landmarks \\ in Black Studies • in Liberation Theology - in Old Testament Studies}

\section{BLACK THEOLOGY \\ A Documentary History, 1966-1979 \\ Gayraud S. Wilmore and James H. Cone, Editors}

In substance scopeand thematic arrangement this is an authoritative interpretation of a major contemporary theological. religious. social. and political movement": - PAUL LEHMAÑN.

Union Theological Seminary

It will become a primary resource wherever theology. Black theology. or the Black religious experience is being investigated researched or taught.

- LAWRENCE N. JONES.

School of Religion. Howard University

672 pages. $\$ 19.95$ cloth $\$ 12.95$ paper

\section{TRIBES OF YAHWEH}

\section{A Sociology of the Religion of Liberated Israel, \\ 1250-1050 B.C.E. \\ Norman K. Cottwald}

Drawing on sociology and anthropology. Gottwald reveals Israel as a tribe which achieved autonomy within Canaanite society. This Israelite counter-society was both egalitarian and socialistic - revolutionary qualities which were reinforced by the religion of Yahweh. By providing both Church and Synagogue with a care. fully researched account of the bases of their traditions. The Tribes of Yahweh makes a notable contribution to a theology of liberation to be developed by Jews and Christians alike.

xxv. 916 pages including 7 charts.

5 indices. 99 pp. notes.

$\$ 29.95$ cloth. \$19.95 paper

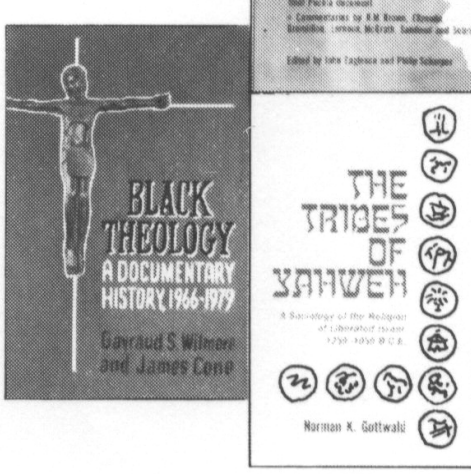

\section{PUEBLA AND BEYOND}

\section{Documents and Commentary}

A first-hand account and assessment of pre-Puebla the Conference itself and its impact on the churches. including the official English translation of the final Document Contents.

1. Overview: Penny Lernoux and Moises Sandoval on the history and highlights of the conterence

II. Documentation: Pope John Paul II's opening address. with introduction and commentary: the final Puebla Document with introduction and commentary.

1II. After Puebla: The significance of Puebla for the Catholic Church in Latin America by John Sobrino. SJ and in North America by Joseph Gremillion: the significance of Puebla for the Protestant Churches of North America by Robert McAfee Brown

384 pages. $\$ 7.95$ paper

Write for catalog

ORBIS BOOKS

Maryknoll NY 10545 


\section{Significant new theological studies...}

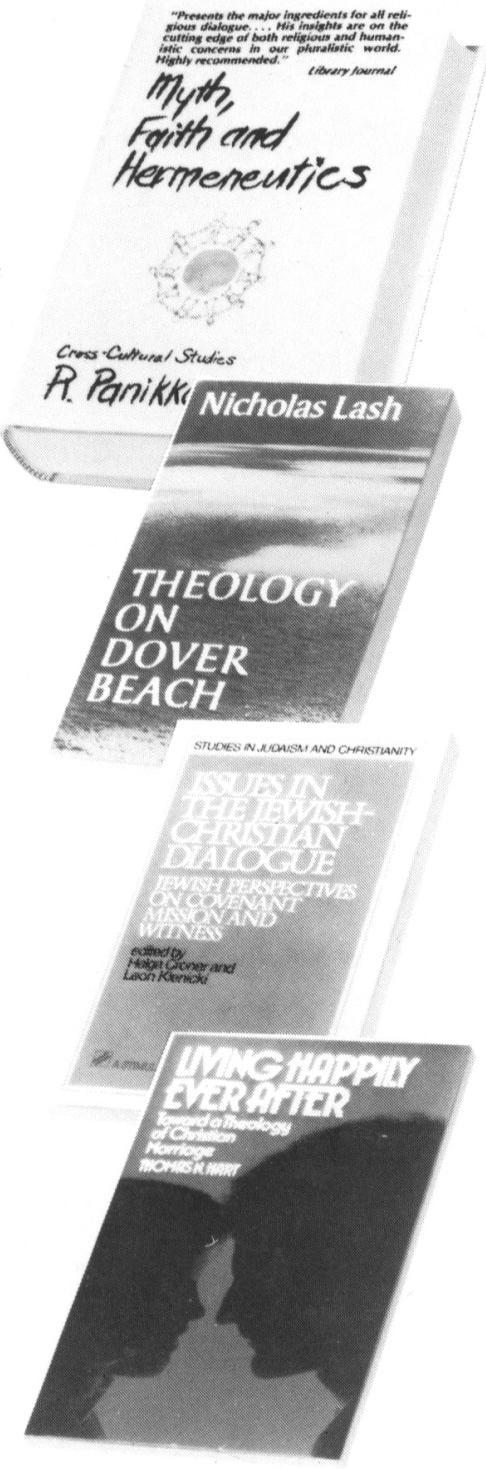

\section{Myth, Faith and Hermeneutics Cross-Cultural Studies}

By R. PANIKKAR. "May well prove to be the catalyst that will break Western hermeneutics out of its cultural entrap. ment, freeing it to function scientifically within a global matrix."

-Ewert H. Cousins, Fordham University. $\$ 19.95$ cloth

\section{Theology on Dover Beach}

By NICHOLAS LASH. Concerned with down-to-earth issues of faith, ministry, continuity and discontinuity, one of England's rising young theologians offers a collection of essays on theological method. $\$ 9.95$ paper

\section{Issues in the Jewish. Christian Dialogue} Jewish Perspectives on Covenant, Mission and Witness

Edited by HELGA CRONER and LEON KLENICKI. Several highly respected Jewish scholars address themselves to various statements published in the last several years by Christian Churches about basic issues central to current Jewish-Christian dialogue.

$\$ 7.95$ paper

\section{Living Happily Ever After}

Toward a Theology of

Christian Marriage

By THOMAS N. HART. Offering contemporary interpretations of sacrament, revelation, grace and the paschal mystery, this book of theological reflection on marriage examines the meaning of marriage today and its role as a specific way of following Christ.

$\$ 3.95$ paper

\section{SUJ PAULTST PRIESS $\begin{aligned} & 545 \text { Island Road. } \\ & \text { Ramsey. New dersey } 07446\end{aligned}$}

